\title{
Cooperation between Austrian and Slovenian libraries
}

Nearly 60 people gathered on 13-14 May 2004 in Maribor (Slovenia) for a conference about the "Cooperation between Austrian and Slovenian libraries" [1].

Austrians and Slovenians haven been neighbours and friends, as well as common citizens, for centuries and cooperation has taken place in the past in many areas, incl. Librarianship.

The date chosen for the conference has been chosen with a special reason: since 1 May 2004 are both Austria and Slovenia, neighbours, EU-countries.

The conference has been organized jointly by the Library of the University of Maribor and the Culture Forum (Cultural Attache) of the Germany Embassy in Ljubljana, the capital of Slovenia. There were 15 speakers from both nations and the proceedings have been published in the original language of the speakers, e.g., German and Slovenian, and there are English-language abstracts of all presentations [2].

The topics highlighted are:

- educational and professional aspects,

- library management,

- digital libraries and portals, and

- consortia/library cooperation.

We have reviewed 3 papers in more detail.

Maria Seissl did highlight the University Organisation and Studies Act, (Universities Act, 2002), which makes universities independent organisations giving them the greatest possible autonomy and self-administration, which has led to quite radical organisational changes in most universities in Austria but most notably in the Vienna University. After long discussions the new organisation plan was passed by the University Council in March 2004 and is currently being implemented.

This reorganising process has also had an effect on Vienna University Library. It has become Vienna University Library and Archive Services, incorporating the formerly independent Central Library of Physics and the University Archive.

Anamarija Rožić-Hristovski, Iztok Humar and Dimitar Hristovski made a presentation about the MojaKnjižnica@CMK (or CMK's Library Portal at the User's Measure).

The Central Medical Library (CMK) at the faculty of Medicine, University of Ljubljana, Slovenia, started to build its library Web site which included a guide to library services and resources in 1997 and has since then been actively involved in its maintenance and improvement. The analysis of the CMK website users' navigational behaviour was carried out by analysing the Web servers log files and using different data-mining methods. The results of our studies and rapidly expanding digital library demanded for a dynamic restructuring of the CMK Web site. Such problems are often solved with customisable and personalised library portals. As the financial and human resources are limited, it was 
decided to customise and extend an existing library portal software solution (MyLibrary from North Carolina State University) from the higher education community. The MyLibrary portal for the CMK was customised to the local needs, and some new functionality, most notably multilingual support, was added. This experience of developing a multilingual library portal could be of interest to some libraries in the European Union.

According to Helmut Hartmann obviously, the main purpose of libraries in consortia in general and in e-journals consortia is the creation of as much synergy effects in collection development, acquisition, administration, controlling, access facilities and, last but not least, funding. However, in spite of all these assets, in daily business activities practically anyone dealing with issues cannot help coming across aggravating problems. After giving a short overview of the conditions in the e-journals market in the starting phase of consortia, the paper identifies and classifies the major reasons for these flaws:

1. Library hostile conditions of agreements for publisher related economic reasons;

2. Loss of synergy effects for lack of organisational and technological infrastructure on publishers' side;

3. Complicated workflow for lack of organisational infrastructure on libraries' side.

Nevertheless, there are undisputed assets in consortia, granting innovation to libraries:

1. Funding;

2. Collection development;

3. License administration;

4. Technological infrastructure.

\section{Appendix. List of the papers with their authors/presenters}

Helga Zotter-Straka

Ausbildung für Informationsberufe in Österreich

Izobraževanje za informacijske poklice $v$ Avstriji

Mag. Maria Seissl

Veränderung bringt Chancen. Das Bibliotheks- und Archivwesen der Universitäts Wien

Spremembe prinašajo možnosti. Bibliotekarstvo in archivstika Univerze na Dunaju

Dr. Manfred Lube

Der Nachlass des philosophen Karl R. Popper als Sondersammlung in de Universitätsbibliothek Klagenfurt

Zapuščina filozofa Karla R. Popperja kot posebna zbirka Univerzitetne knjižnice Celovec

\section{Helmut Hartmann}

Konsortien im bibliothekarischen Alltage - Ballast oder Innovationsfaktor?

Konzorciji v knjižničarskem vsakdanu - breme ali inovacijske možnosti?

Dr. Heinz Hauffe

De wissenschaftliche Informationsmarkt - seine Teilnehmer und seine Spielregeln

Znanstveni informacijski trg - njegovi udeleženci in njegova pravila 
Bruno Sperl

Forschung und Entwicklung, internationale Projekte der Universitätsbibliothek Graz

Raziskovanje in razvoj, mednarodni projekti Univerzitetne knjižnice Gradec

Dr. Sigrid Reinitzer

Strategisches Management als zentrale Aufgabe für Slawistik

Slovensko, slovenistično v graški specialni knjižnici za slavistiko

Dr. Jože Urbanija

Izobraževanje knjižničarjev v Sloveniji

Bibliothekarenausbildung in Slowenien

Miroslav Kolarič

Predstavitev novosti v programski opremi COBISS3 V3.0

Neuigkeiten im COBISS3 V3.0 System Software

Ivan Kanič

Konzorciji - možnosti mednarodnega sodelovanja

Konsortien - Möglichkeiten der internationalen Kooperation

Mojica Dolgan-Petrič

Finančna avtonomnost univerzenova priložnost za visokošolske knjižnice

Finanzielle Autonomie der Universität - neue Gelegenheit für die Hochschulbibliotheken

Dr. Anamarija Rožić-Hristovski, Iztok Humar, Dimitar Hristovski

MojaKnjižnica@CMK: knjižnični portal po meri uporabnika

MojaKnjižnica@CMK: Bibliotheksportalnach Maß des Benutzers

Mag. Zdenka Petermanec

Vloga visokošolskega knjižničarja pri informacijskem opismenjevanju

Die Rolle des Hochschulbibliothekars bei Informationsalphabetisierung

Mateja Škofljanec

Avstrijska čitalnica v Univerzitetni knjižnici Maribor kot most med slovenskimi in avstrijskimi knjižnicami in institucijami

Österreich-Bibliothek Maribor als Brücke zwischen slowenischen und österreichischen Bibliotheken und Institutionen

\section{References}

[1] Sodelovanje slovenskih in avstrijskih knjižnic, Kooperation der österreichischen und slowenischen Bibliotheken, Zbornik mednarodnega posvetovanja, Maribor, 13-14 Maj 2004.

[2] CIP - Kataložni zapis o publikaciji, Univerzitetna knjižnica Maribor, 02(063)(082), Sodelovanje slovenskih in avstrijskih knjižnic (Kooperation der österreichischen und slowenischen Bibliotheken): Zbornik mednarodnega posvetovanja, Maribor 13-14 maj 2004/[urednica Mateja Škofljanec; sourednica Jerneja Ferlež]. - Maribor: Univerzitetna knjižnica, 2004, ISBN 961-90036-3-2. 